\title{
Evaluation of effectiveness of intermittent inhalational entonox in comparison with opioid tramadol for labour analgesia
}

\author{
Amit Kumar' ${ }^{1}$ Y. S. Chandel ${ }^{2 *}$ \\ ${ }^{1}$ Department of Obstetrics and Gynecology, Military Hospital, Bhuj, Gujrat, India \\ ${ }^{2}$ Department of Obstetrics and Gynecology, Army College of Medical Sciences and Base Hospital, Delhi Cantt, Delhi, \\ India
}

Received: 02 August 2017

Revised: 12 August 2017

Accepted: 01 September 2017

\section{*Correspondence:}

Dr. Y. S. Chandel,

E-mail: yschandel1@gmail.com

Copyright: ( ) the author(s), publisher and licensee Medip Academy. This is an open-access article distributed under the terms of the Creative Commons Attribution Non-Commercial License, which permits unrestricted non-commercial use, distribution, and reproduction in any medium, provided the original work is properly cited.

\begin{abstract}
Background: Childbirth is an emotion-filled event and the mother needs to bond with her newborn baby as early as possible. Any intervention that leads to improvement in pain relief is worthy of investigation. Entonox, opioids as well as epidural analgesia are effective means for pain relief in labour, notwithstanding their shortcomings. The objectives of study are to compare the effectiveness of intermittent inhalational Entonox for labour analgesia with intramuscular opioid (Tramadol) and to compare the effects of Entonox and Tramadol as labour analgesia on the maternal and fetal outcome of labour.

Methods: The study was a prospective randomized, comparative study of two established techniques of labour analgesia. The study was carried out in 100 subjects. These subjects are divided into two groups. Group A - Tramadol Group: 50 women in active labour who received $100 \mathrm{mg}$ tramadol intramuscularly with repeat dose of 50mg tramadol 4 hourly. Group B - Entonox Group: 50 women in active labour who received entonox for labour analgesia.

Results: The mean VAS (visual analogue score) i.e. the pain score in group I (Tramadol) was $4.58 \pm 1.54$ and Group II (Entonox) was $4.02 \pm 1.99$ which is significantly low when compared to Group I (Tramadol) $p<0.001$. Study also showed that both the analgesics Entonox as well as Tramadol does not cause any significant change when compared for duration of labor. The rate of instrumental assisted vaginal deliveries and normal vaginal deliveries were almost equal in both the groups. In our study, the mean overall satisfaction level of the parturients in group II (Entonox) at 1 $\mathrm{hr}$ post delivery was $(5.06 \pm 1.42)$ and $24 \mathrm{hr}$ post delivery was $(6.64 \pm 1.66)$ which was more when compared with tramadol group. The difference was statistically significant ( $p$ value was $<0.001$ ). This indicates that overall satisfaction level of the parturients is more with the use of Entonox when compared with Tramadol.

Conclusions: Therefore, it is concluded that intermittent inhalational Entonox provides better labour analgesia then intramuscular opioid Tramadol.
\end{abstract}

Keywords: Entonox, Labour analgesia, Tramadol, Visual analogue scale

\section{INTRODUCTION}

Giving birth is a painful process. Any intervention that leads to improvement in pain relief is worthy of investigation $^{1}$. Opioid as well as epidural analgesia is effective means for pain relief in labour, notwithstanding their shortcomings. Data regarding Entonox (50\% Nitrous Oxide and 50\% Oxygen mixture) for labour analgesia is not available in current Indian literature. Use of Entonox offers many apparent advantages over the 
existing methods i.e. Entonox being a patient controlled system, offers rapid reversibility and there is no possibility of overdose. It also assures a higher oxygen delivery to fetus, compared to ambient air.

Tramadol is a synthetic 4-phenyl-piperidine analogue of codeine. It is a central analgesic with a low affinity for $\mu$ opioid receptor. It inhibits serotonin and norepinephrine opioid receptor. neuronal reuptake. ${ }^{2}$ Tramadol is less likely to cause neonatal respiratory depression. ${ }^{3}$ Tramadol also inhibits type-3 muscarinic receptor (M3); which primarily mediates gastric gland secretion and smooth muscle contraction. ${ }^{4}$ Tramadol has been used as an analgesic since the late 1970s and has become one of the most popular analgesics of its class. Tramadol is less likely to cause neonatal respiratory depression and hence it has been recommended for analgesia in parturients undergoing vaginal delivery. ${ }^{5}$ Hence, the study has been planned to compare the effectiveness of intermittent inhalational Entonox for labour analgesia with intramuscular opioid (Tramadol) and to compare the effects of Entonox and Tramadol as labour analgesia on the maternal and fetal outcome of labour.

\section{METHODS}

This is a randomized, prospective, comparative study of two established techniques of labour analgesia.

100 pregnant patients reporting to base hospital Delhi Cantt for delivery fulfilling the selection criteria were enrolled after obtaining an informed written consent.

\section{Inclusion criteria}

Singleton pregnancy in cephalic presentation, gestational age between 34 to 42 weeks, spontaneous/induced labour, cervical dilatation of $3 \mathrm{~cm}$ or more, no evidence of cephalopelvic disproportion, planned for vaginal delivery.

\section{Exclusion criteria}

Known allergies to opiates/Entonox. Post LSCS pregnancy. Severe concomitant disease including cardiac and renal dysfunctions, known patients of bronchial asthma and chronic obstructive pulmonary diseases or URTI.

Patients were divided randomly, using random number table into 2 groups:

- Group A-Tramadol Group: 50 women in active labour who receive $100 \mathrm{mg}$ tramadol intramuscularly. Repeat dose of $50 \mathrm{mg}$ tramadol injected intramuscularly after 4 hours except in cases where the women reach the end of 1st stage or enter 2nd stage of labour.

- Group B-Entonox Group: 50 women in active labour who received entonox for labour analgesia.

\section{Analgesic efficacy}

Analgesic efficacy is assessed by using visual analogue score (VAS). The patients were asked to record the intensity of labour pain on a $10-\mathrm{cm}$ analogue scale ranging from 0 for no pain to 9 for the worst pain imaginable. Pain recording done half hourly after administration of the first administration of study drugs.

\section{Statistical analysis}

Demographic data like age, occupation, education of the parturient, as well as antenatal risk factors and complications were recorded and analyzed using Statistical analysis like SPSS for parametric data. All differences with p-value below 0.05 were labeled as statistically significant. Proportions were analysed by Chi-square test. VAS score was compared using Student's t test.

\section{RESULTS}

A total of 100 pregnant patients were included in the present study. These patients were divided in to two group:

Group I Tramadol Group: 50 women in active labour who received $100 \mathrm{mg}$ tramadol intramuscularly with repeat dose of 50mg tramadol 4 hourly.

Group B - Entonox Group: 50 women in active labour who received Entonox for labour analgesia. Table 1 and figure1shows comparison of pain score (VAS Min: Maximum pain relief achieved during the study period) between Groups I and II.

The mean VAS (visual analogue score) i.e. the pain score in group II was significantly low when compared to Group I (Tramadol) with $\mathrm{P}<0.001$ ( $2 \times 4$ Fisher Exact test).

Table 1: Comparison of pain score (VAS) between GP I and GP II.

\begin{tabular}{|c|c|c|c|c|}
\hline \multirow[t]{2}{*}{ Pain score } & \multicolumn{2}{|c|}{$\begin{array}{l}\text { Group I }(\mathbf{n}=\mathbf{5 0}) \\
\text { tramadol }\end{array}$} & \multicolumn{2}{|c|}{$\begin{array}{l}\text { Group II }(\mathbf{n}=50) \\
\text { entonox }\end{array}$} \\
\hline & No & $\%$ & No & $\%$ \\
\hline No pain (0-1) & 4 & 8.0 & 6 & 12.0 \\
\hline Mild pain (2-3) & 12 & 24.0 & 29 & 58.0 \\
\hline $\begin{array}{l}\text { Moderate pain } \\
(4-5)\end{array}$ & 33 & 66.0 & 8 & 16.0 \\
\hline $\begin{array}{l}\text { Severe pain } \\
(6-7)\end{array}$ & 1 & 2.0 & 7 & 14.0 \\
\hline $\begin{array}{l}\text { Worst pain } \\
(8-9)\end{array}$ & 0 & 0.0 & 0 & 0.0 \\
\hline Mean \pm SD & \multicolumn{2}{|c|}{$4.58 \pm 1.54$} & \multicolumn{2}{|c|}{$4.02 \pm 1.99$} \\
\hline Inference & \multicolumn{4}{|c|}{$\begin{array}{l}\text { Pain score by VAS for Group II is } \\
\text { significantly low when compared to } \\
\text { Group I with } \mathrm{P}<0.001 \text { ( } 2 \times 4 \text { Fisher } \\
\text { Exact test) }\end{array}$} \\
\hline
\end{tabular}

VAS: visual analogue score 
Table 2: Mean levels of pain score before and after treatment of drugs in GP I and GP II.

\begin{tabular}{|llll|}
\hline VAS score & $\begin{array}{l}\text { Group I } \\
(\mathbf{n}=50)\end{array}$ & $\begin{array}{l}\text { Group II } \\
(\mathrm{n}=50)\end{array}$ & $\begin{array}{l}\text { P } \\
\text { value }\end{array}$ \\
\hline Before treatment & $6.46 \pm 2.18$ & $7.06 \pm 1.42$ & 0.106 \\
\hline After treatment & $5.98 \pm 1.55$ & $5.64 \pm 1.66$ & 0.292 \\
\hline Significance & 0.200 & $<0.001$ & - \\
\hline
\end{tabular}

Table 2 shows mean levels of pain score before and after treatment of drugs in Group I and II. The mean levels of pain score in group I (Tramadol Group) before and after treatment was statistically not significant. The mean levels of pain score in group II (Entonox) before and after treatment was statistically significant $(\mathrm{p}<0.001)$.

Table 3: Mean levels of comparison of maternal outcome between two groups of patients.

\begin{tabular}{|c|c|c|c|}
\hline $\begin{array}{l}\text { Maternal } \\
\text { Outcome }\end{array}$ & $\begin{array}{l}\text { Group I } \\
(n=50)\end{array}$ & $\begin{array}{l}\text { Group II } \\
(\mathrm{n}=50)\end{array}$ & P value \\
\hline \multicolumn{4}{|c|}{ Duration of labour } \\
\hline $\begin{array}{l}1^{\text {st }} \text { stage } \\
\text { labour }\end{array}$ & $221.74 \pm 131.54$ & $232.34 \pm 104.47$ & 0.668 \\
\hline $\begin{array}{l}2^{\text {nd }} \text { stage } \\
\text { labour }\end{array}$ & $32.09 \pm 19.72$ & $42.92 \pm 16.07$ & 0.145 \\
\hline $\begin{array}{l}3^{\text {rd }} \text { stage } \\
\text { labour }\end{array}$ & $10.61 \pm 6.43$ & $9.80 \pm 4.01$ & 0.453 \\
\hline \multicolumn{4}{|c|}{ Mode of delivery } \\
\hline $\begin{array}{l}\text { Normal } \\
\text { vaginal } \\
\text { delivery }\end{array}$ & $43(86.0 \%)$ & $42(84.0 \%)$ & 1.000 \\
\hline $\begin{array}{l}\text { Instrume } \\
\text { ntal } \\
\text { assisted } \\
\text { delivery }\end{array}$ & $3(6.0 \%)$ & $4(8.0 \%)$ & 1.000 \\
\hline LSCS & $4(8.0 \%)$ & $4(8.0 \%)$ & 1.000 \\
\hline \multicolumn{4}{|c|}{ Side effects of analgesic } \\
\hline Nausea & $1(2.0 \%)$ & $8(16.0 \%)$ & $0.031 *$ \\
\hline $\begin{array}{l}\text { Mild } \\
\text { vomiting }\end{array}$ & 0 & $3(6.0 \%)$ & 0.242 \\
\hline $\begin{array}{l}\text { Moderate } \\
\text { to severe } \\
\text { vomiting }\end{array}$ & 0 & $1(2.0 \%)$ & 1.000 \\
\hline $\begin{array}{l}\text { Motor } \\
\text { block }\end{array}$ & $0.0 \%$ & $0.0 \%$ & $\begin{array}{l}\text { Not } \\
\text { significant }\end{array}$ \\
\hline \multicolumn{4}{|c|}{ Post natal complications } \\
\hline & $8(16.0 \%)$ & $6(12.0 \%)$ & 0.774 \\
\hline
\end{tabular}

Table 3 shows comparison of maternal outcome between two groups of patients. The mean levels of duration of labour of stages first and second were more in group II as compared to group I but there were no significant variations. The mean levels of duration of labour of stage third was less in group II as compared to group I but not significant.

Normal vaginal deliveries were more in group I as compared to in group II. Instrumental assisted deliveries were less in group I as compared to in group II. Incidence of emergency caesarean deliveries was same in both the groups but not statistically significant.

The incidence of nausea was more in group II in comparison to group I and statistically significant ( $p<0.001)$. The incidence of mild vomiting was more in group II in comparison to group I and not statistically significant $(\mathrm{p}>0.001)$.

The incidence of overall post natal complications (PPH, puerperal pyrexia, urinary retention) were more in group I in comparison to group II and not statistically significant $(\mathrm{p}<0.001)$.

Table 4: Comparison of overall maternal satisfaction with analgesia $1 \mathrm{hr}$ and $24 \mathrm{hr}$ post delivery between two groups of patients.

\begin{tabular}{|lll|}
\hline Maternal satisfaction & $\begin{array}{l}\text { Group I } \\
(\mathrm{n}=50)\end{array}$ & $\begin{array}{l}\text { Group II } \\
(\mathrm{n}=50)\end{array}$ \\
\hline 1 hr after delivery & $4.46 \pm 2.18$ & $5.06 \pm 1.42$ \\
\hline 24 hr after delivery & $4.98 \pm 1.55$ & $6.64 \pm 1.66$ \\
\hline Significance (p) & 0.200 & $<0.001$ \\
\hline
\end{tabular}

Table 4 shows comparison of overall maternal satisfaction with analgesia $1 \mathrm{hr}$ and $24 \mathrm{hr}$ post delivery between two groups of patients. The mean satisfaction level in group I (Tramadol) $1 \mathrm{hr}$ after delivery and $24 \mathrm{hr}$ after delivery $\mathrm{p}$ value was 0.200 showing significant difference statistically. The mean satisfaction level in group II (Entonox) $1 \mathrm{hr}$ after delivery and $24 \mathrm{hr}$ after delivery $\mathrm{p}$ value was $<0.001$ showing statistically significant difference.

Table 5: Comparison of neonatal outcome in both the groups.

\begin{tabular}{|c|c|c|c|}
\hline Fetal outcome & $\begin{array}{l}\text { Group I } \\
(n=50)\end{array}$ & $\begin{array}{l}\text { Group II } \\
(\mathrm{n}=50)\end{array}$ & $\begin{array}{l}P \\
\text { value }\end{array}$ \\
\hline \multicolumn{4}{|l|}{ Fetal distress } \\
\hline Yes & $4(8.0 \%)$ & 0 & \multirow{2}{*}{0.117} \\
\hline No & $46(92.0 \%)$ & $50(100.0 \%)$ & \\
\hline \multicolumn{4}{|c|}{ Apgar score at $1 \mathrm{~min}$} \\
\hline$<7$ & $2(4.0 \%)$ & $2(4.0 \%)$ & \multirow{2}{*}{ NS } \\
\hline$>7$ & $48(96.0 \%)$ & $48(96.0 \%)$ & \\
\hline \multicolumn{4}{|c|}{ Apgar score 5 min } \\
\hline$<7$ & 0 & $1(2.0 \%)$ & \multirow{2}{*}{ NS } \\
\hline$>7$ & $50(100.0 \%)$ & $49(98.0 \%)$ & \\
\hline \multicolumn{4}{|c|}{ NICU admission } \\
\hline Yes & $3(6.0 \%)$ & $1(2.0 \%)$ & \multirow{2}{*}{0.617} \\
\hline No & $47(94.0 \%)$ & $49(98.0 \%)$ & \\
\hline \multicolumn{4}{|c|}{ Respiratory depression } \\
\hline Yes & $3(6.0 \%)$ & $1(2.0 \%)$ & \multirow{2}{*}{0.617} \\
\hline No & $47(94.0 \%)$ & $49(98.0 \%)$ & \\
\hline \multicolumn{4}{|l|}{ Breast feeding } \\
\hline No & $1(2.0 \%)$ & $1(2.0 \%)$ & \multirow{2}{*}{ NS } \\
\hline Yes & $49(98.0 \%)$ & $49(98.0 \%)$ & \\
\hline \multicolumn{4}{|c|}{ Birth weight (grams) } \\
\hline$<2500$ & $3(6.0 \%)$ & $3(6.0 \%)$ & \multirow{2}{*}{ NS } \\
\hline$>2500$ & $47(94.0 \%)$ & $47(94.0 \%)$ & \\
\hline
\end{tabular}


Table 5 shows comparison of overall maternal satisfaction with analgesia $1 \mathrm{hr}$ and $24 \mathrm{hr}$ post delivery between two groups of patients. The incidence of fetal distress (non reassuring, category II and III CTG tracing) were more in group I in comparison to group II and not significant $(\mathrm{p}>0.001)$.

The incidence of Apgar score $<7$ were the same in both the groups showing insignificant difference statistically. The incidence of Apgar score $<7$ were more in group II (Entonox) in comparison to group I (Tramadol), showing insignificant difference statistically.

The incidence of NICU admission were more in group I (Tramadol) in comparison to group II (Entonox) with $\mathrm{p}$ value of 0.617 , showing insignificant difference statistically. The incidence respiratory depression were more in group I (Tramadol) in comparison to group II (Entonox) with $\mathrm{p}$ value of 0.617 , showing insignificant difference statistically.

\section{DISCUSSION}

Management of labour pain continues to pose a practical challenge to the health care provider. Many new strategies continue to evolve in an effort to alleviate labour pain. The key importance is to provide effective labour analgesia with minimum side effects to achieve better maternal and neonatal outcome.

This study was designed to compare the effects of Entonox and Tramadol on labour analgesia and its maternal and fetal outcome. As seen from table 1, the visual analogue score (VAS) i.e. the pain score is significantly low in group II (Entonox) compared to Group I (Tramadol) with $\mathrm{P}<0.001$ This means that labour analgesia is more effective with the use of intermittent inhalational Entonox when compared to intramuscular opioid Tramadol.

Long and Yue in his study compared IV Tramadol with the dose of $1 \mathrm{mg} / \mathrm{kg}$, with combined spinal-epidural analgesia (CSEA) with Ropivacaine $2.5 \mathrm{mg}$ and Fentanyl $5 \mu \mathrm{g} .{ }^{6} \mathrm{He}$ found that both groups showed good pain relief. In comparison with Tramadol group, the VAS pain score was lower in CSEA group $(\mathrm{P}<0.05)$. Li E and Weng $\mathrm{L}$ in a study with 90 primigravide compared Dihydroetorphine hydrochloride (DHE) and Tramadol. ${ }^{7}$ They found that effective rate of pain relief was more in DHE group (67\%) compared to tramadol group (63\%) (P $>0.05)$. Pain relief with Entonox has been analysed using other inhalational agents.

Yeo ST et al compared sevoflurane and entonox for analgesia during labour in 32 healthy parturients. ${ }^{8}$ They observed that the median (IQR [range]) pain relief scores were significantly higher for sevoflurane 67 (55-74 [33$100]) \mathrm{mm}$ than for Entonox 51 (40-69.5 [13-100]) $\mathrm{mm}$ $(P<0.037)$. They concluded that self-administered sevoflurane at subanaesthetic concentration $(0.8 \%)$ can provide useful pain relief during the first stage of labour, and to a greater extent than Entonox

The mean pain score before treatment (i.e. before administration of analgesia) and after treatment (i.e. recorded $1 \mathrm{hr}$ after delivery) was significantly lower with the use of Entonox.

The mean pain score in group II (Entonox) before treatment was $7.06 \pm 1.42$ and after treatment was $5.64 \pm 1.66$, with $\mathrm{p}$ value of $<0.001$ showing significant difference statistically. The mean pain score in group I (Tramadol) before treatment was $6.46 \pm 2.18$ and after treatment was $5.98 \pm 1.55$ with $\mathrm{p}$ value of 0.20 showing statistically insignificant difference. This indicates that Entonox provides better pain relief in comparison with Tramadol. This is consistent with the previous studies. ${ }^{9-13}$

Bitsch et al compared Tramadol with pethedin in labour analgesia and found identical analgesic efficiency in both the group. ${ }^{14}$ Jain et al compared analgesic efficacy of intramuscular opioids: meperidine and tramadol with epidural analgesia. ${ }^{15}$ The analgesic efficacy and maternal satisfaction is better with epidural analgesia than with opioids. Effects of these drugs on maternal outcome showed (Table 4).

That duration of first stage of labour was more in group II (Entonox) $232.34 \pm 104.47 \mathrm{~min}$. in comparison to group I (Tramadol) $221.74 \pm 131.54 \mathrm{~min}$. With $\mathrm{p}$ value of 0.668 , showing insignificant difference statistically. Duration of second stage of labour was more in group II (Entonox) $42.92 \pm 16.07 \mathrm{~min}$. in comparison to group I (Tramadol) $32.09 \pm 19.72 \mathrm{~min}$. With $\mathrm{p}$ value of 0.453 , showing insignificant difference statistically.

Yeo ST et al compared sevoflurane and entonox for analgesia during labour in 32 healthy parturients. $8 \mathrm{He}$ found that there was no significant difference in duration of labour. Jain et al compared analgesic efficacy of intramuscular opioids: meperidine and tramadol with epidural analgesia in 128 term nulliparous women with singleton pregnancy. ${ }^{16}$ They observed that epidural caused a significant prolongation of first stage of labour $(\mathrm{P}<0.05)$ and second stage of labour $(\mathrm{P}<0.01)$. Tramadol doesn't cause any significant difference in prolongation of labour.

Effect on mode of deliveries of these analgesics showed instrumental assisted vaginal deliveries and normal vaginal deliveries were almost equal in both the groups. Emergency caesarean deliveries have same incidence i.e. $8.0 \%$.in both the groups. The difference in incidence by mode of deliveries in both the groups was statistically not significant. Thus, Tramadol and Entonox did not have any effect on mode of delivery. ${ }^{6,16}$

Side effect of analgesics showed nausea, which was more in group II (Entonox) $8(16.0 \%)$ in comparison to group I 
(Tramadol) $1(2.0 \%)$ with $\mathrm{p}$ value of 0.031 , showing significant difference statistically.

The incidence of mild vomiting was more in group II (Entonox) $3(6.0 \%)$ in comparison to group I (Tramadol) $0 \%$ with $\mathrm{p}$ value of 0.242 , showing insignificant difference statistically. This indicates that Entonox causes more nausea and vomiting when compared with Tramadol for labour analgesia. ${ }^{8,6}$

The incidence of overall post natal complications [urinary retention (1), puerperal pyrexia (2), PPH (3)] were more in group I (Tramadol) i.e. $8(16.0 \%)$, in comparison to group II (Entonox) i.e. 6(12.0\%) with p value of 0.774 , showing insignificant difference statistically. This indicates that Entonox and Tramadol do not cause significant post natal complications. ${ }^{8,14,17}$

The overall satisfaction level of the parturients in group II (Entonox) at $1 \mathrm{hr}$ post delivery was $5.06 \pm 1.42$ and $24 \mathrm{hr}$ post delivery was $6.64 \pm 1.66$ which was more when compared with tramadol group. The difference was statistically significant ( $p$ value was $<0.001$ ). It means that the satisfaction level increases with increase in time post delivery with the use of Entonox. ${ }^{16,18}$ In this respect Entonox would be a better choice of labour analgesia when compared to Tramadol.

The effects of these analgesic on neonatal outcome showed (Table 5) that the incidence of fetal distress (non reassuring, category IIandIII CTG tracing) were more in group I (Tramadol) 4(8.0\%) in comparison to group II (Entonox) $0(0.0 \%)$ with $p$ value of 0.117 , showing insignificant difference statistically on apgar score $<7$ are the same in both the groups showing insignificant difference statistically (Table 5). ${ }^{8,17,19}$

The incidence of respiratory depression in the neonates was more in group I (Tramadol) i.e. 3(6.0\%) in comparison to group II (Entonox) i.e. 1(2.0\%), with $\mathrm{p}$ value of 0.617 , showing insignificant difference statistically (Table 5). ${ }^{8,16}$

These findings indicate that use of Tramadol as well as Entonox for labour analgesia does not increase the risk of adverse neonatal outcome. Both are safe for the neonates when use for labour analgesia.

\section{CONCLUSION}

Therefore, it is concluded that both opioid is safer labour analgesia. The Intermittent inhalational Entonox provides better labour analgesia, by keeping the patients quiet and relaxed in between the pains. The overall maternal satisfaction is more with Entonox as compared to Tramadol. Tramadol has more side effect than Entonox.

Funding: No funding sources Conflict of interest: None declared
Ethical approval: The study was approved by the Institutional Ethics Committee

\section{REFERENCES}

1. Barclay L. Postoperative pain relief for caesarean delivery reviewed. Cochrane Database Syst Rev. 2009.

2. Vickers MD, O'Flaherty D, Szekely SM, Read M, Yoshizumi J. Tramadol: pain relief by an opioid without depression of respiration. Anaesthesia. 1992;47:291-6.

3. Viegas OA, Khaw B, Ratnam SS. Tramadol in labour pain inprimiparous patients. A prospective comparative clinical trial. Eur J Obstet Gynecol. 1993;49:131-5.

4. Shiga Y, Minami K, Shiraishi M, Uezono Y, Murasaki O, Kaibara M et al. The inhibitory effects of tramadol on muscarinic receptor-induced responses in Xenopus oocytes expressing cloned M3 receptors. Anesth Analg. 2002;95:1269-3.

5. Vickers MD, O'Flaherty D, Szekely SM, Read M, Yoshizumi J. Tramadol: pain relief by an opioid without depression of respiration. Anaesthesia. 1992;47:291-6.

6. Long J, Yue Y. Patient controlled intravenous analgesia with tramadol for labor pain relief. Chin Med J (Engl). 2003;116(11):1752-5.

7. Li E, Weng L. Influence of dihydroetorphine hydrochloride and tramadol on labor pain and umbilical blood gas. Zhonghua Fu Chan Ke Za Zhi. 1995;30(6):345-8.

8. Yeo ST, Holdcroft A, Yentis SM, Stewart A, Bassett P. Analgesia with sevoflurane during labour: II. Sevoflurane compared with Entonox for labour analgesia. Br J Anaesth. 2007;98(1):110-5.

9. Kangas-Saarela T, Kangas-Karki K. Pain and pain relief in labour: Parturients' experiences. Int J Obstet Anesth. 1994;3:67-74

10. Abboud TK, Shnider SM, Wright RG, Rolbin SH, Craft JB, Henriksen EH et al. Enflurane analgesia in obstetrics. Anesth Analg. 1981;60:133-13.

11. Westling F, Milsom I, Zetterström H, Ekström-Jodal B. Effects of nitrous oxide/oxygen inhalation on the maternal circulation during vaginal delivery. Acta Anaesthesiol Scand. 1992;36:175-181.

12. Chia YT, Arulkumaran S, Chua S, Ratnam SS. Effectiveness of transcutaneous electric nerve stimulator for pain relief in labour. Asia Oceania J Obstet Gynecol. 1990;16:145-51.

13. Reynolds F. Pain relief in labour. $\mathrm{Br} \mathrm{J}$ Obstet Gynecol. 1993;100:979-83.

14. Bitsch M, Emmrich J, Hary J, Lippach G, Rindt W. Obstetrical analgesia with tramadol. Fortschr Med. 1980;98(16):632-4.

15. Jain S, Arya VK, Gopalan S, Jain V. Analgesic efficacy of intramuscular opioids versus epidural analgesia in labor. Int $\mathrm{J}$ Gynecol Obstet. 2003;83(1):19-27. 
16. Rosen MA. Nitrous oxide for relief of labor pain: a systematic review. Am J Obstet Gynecol. 2002;186(suppl):S110-26.

17. Keskin HL, Keskin EA, Avsar AF, Tabuk M, Caglar GS. Pethidine versus tramadol for pain relief during labor. Int J Gynecol Obstet. 2003;82(1):11-6.

18. Committee on Nitrous Oxide and Oxygen Analgesia in Midwifery Clinical trials of different concentrations of oxygen and nitrous oxide for obstetric analgesia. Br Med J. 1970;1:709-713.

19. Kainz C, Joura E, Obwegeser R, Plockinger B, Gruber W. Zeitschrift fur Geburtshilfe und
Perinatologie. Effectiveness and tolerance of tramadol with or without an antiemetic and pethidine in obstetric analgesia. Geburtshilfe Perinatol. 1992;196(2):78-82.

Cite this article as: Kumar A, Chandel YS.

Evaluation of effectiveness of intermittent inhalational entonox in comparison with opioid tramadol for labour analgesia. Int J Reprod Contracept Obstet Gynecol 2017;6:4538-43. 